\title{
Media Sosial sebagai Strategi Komunikasi Politik Partai Golkar dalam Melakukan Pendidikan Politik
}

\author{
Andiwi Meifilina \\ Program Studi Ilmu Komunikasi, Universitas Islam Balitar \\ Email: andiwimeifilina1@yahoo.co.id
}

\begin{abstract}
Apart from being a means to communicate and absorb constituents' aspirations, social media can also be used to create a positive image of legislative candidate and political party. The purpose of this study is to analyze the political communication strategy of the Blitar Regency Golkar party through social media as political education on the development of community digital literacy and to uncover and analyze the factors that hinder the political communication strategy used by the party. This study uses descriptive qualitative method with data collection technique in a documentary manner. The result shows that the political communication strategy carried out by the Golkar party in Blitar Regency is to determine the communication components based on the communication concept of Harold D. Laswell, namely communicator, message, media, communicant, and effect. In implementing this strategy, there are internal and external constraints. Internal constraints include the psychological condition of young people and operational funds that are the responsibility of legislative candidate. Meanwhile, external constraints include media coverage of controversial statements by political elites, the formation of negative public opinion, and competition from other political parties.
\end{abstract}

Keywords: political communication strategy; social media; political education

\begin{abstract}
Abstrak: Selain sebagai sarana untuk berkomunikasi dan menyerap aspirasi konstituen, media sosial juga dapat digunakan untuk membentuk citra positif calon anggota legislatif dan partai politik. Tujuan penelitian ini untuk menganalisis strategi komunikasi politik partai Golkar Kabupaten Blitar melalui media sosial sebagai pendidikan politik dalam pengembangan literasi digital masyarakat dan untuk mengungkap dan menganalisis faktor-faktor apa saja yang menghambat strategi komunikasi politik yang digunakan partai tersebut. Penelitian ini menggunakan metode kualitatif deskriptif dengan teknik pengumpulan data secara dokumentatif. Hasil penelitian menunjukkan bahwa strategi komunikasi politik yang dilakukan partai Golkar Kabupaten Blitar adalah menetapkan komponen-komponen komunikasi berdasarkan konsep komunikasi Harold D. Laswell, yaitu komunikator, pesan, media, komunikan, dan efek. Dalam penerapan strategi tersebut terdapat kendala internal dan eksternal. Kendala internal meliputi kondisi psikologis kaum muda dan dana operasional yang menjadi tanggung jawab calon anggota legislatif. Sementara kendala eksternal meliputi pemberitaan media terkait beberapa pernyataan kontroversial elit politik, terbentuknya opini publik yang negative, dan persaingan dari partai-partai politik lain.
\end{abstract}

Kata kunci: strategi komunikasi politik; media sosial; pendidikan politik

\section{Pendahuluan}

Perkembangan teknologi komunikasi pada era digital telah menggeser peran media konvensional. Hal ini terjadi terutama bersamaan dengan hadirnya media baru (new media) atau dalam istilah yang lain media digital. Media baru menjadi salah satu sarana yang dapat memadukan teks, suara, gambar, dan video dengan menggunakan teknologi computer yang berbeda dari media konvensional. Media baru merupakan terminoologi yang menjelaskan mengenai teknologi komunikasi digital yang terkomputerisasi dan terhubung ke dalam jaringan 
internet (Flew, 2005; Efendi et al., 2017). Media baru memberikan dampak yang cukup besar terhadap kehidupan sosial masyarakat, sehingga dapat merubah pola kehidupan mereka baik dalam aspek budaya, berpikir, dan berkomunikasi (Kristiyono, 2015). Internet menjadi penyokong utama kelahiran media baru dan ini juga berdampak pada terciptanya bentuk baru interaksi sosial kegiatan komunikasi manusia (Nursalim, 2017).

Bentuk baru kegiatan berkomunikasi masyarakat bisa dilihat dari intensnya penggunaan media sosial sebagai salah satu bentuk produk dari media baru. Sebuah penelitian yang dilakukan Nasrullah pada tahun 2015 menyebutkan bahwa dari 62 juta lebih pengguna internet di Indonesia, sekitar 38 juta orang terdaftar serta memiliki akun di media sosial Facebook (Rafiq, 2020). Para pengguna media sosial dapat dengan mudah bergabung dalam beberapa aktivitas dan interaksi seperti terjadinya kegiatan pertukaran informasi (Cahyono, 2016). Terlebih lagi dewasa ini hadir beberapa media sosial yang sering digunakan seperti, Youtube, Facebook, Twitter, dan Instagram. Media sosial ini membuat masyarakat menjadi aktif berselancar di dunia maya tanpa ada batasan ruang dan waktu. Media sosial juga dapat menjadi wadah bagi pengguna dalam menampung aspirasi dan kreatifitas (Sibarani, 2021). Media sosial memungkinkan akan terjadinya interaksi brand conversation, brand mention, dan social metric lainnya berupa follower, like dan share. Hal ini dapat memberikan pengaruh yang besar dalam keputusan pembelian (Priansa, 2017).

Media sosial yang banyak digunakan kalangan milenial menyebabkan terjadinya beberapa permasalahan, di antaranya kasus bullying, prostitusi online, pornografi serta konflik politik dalam mendukung kandidat pilkada dan pemilu yang akan datang di tahun 2024. Adanya permasalahan yang sering muncul dalam penelitian ini adalah pentingnya mengantisipasi penyelenggaraan pelatihan literasi media di kalangan milenial. Pendidikan bertujuan untuk mengembangkan baik pemahaman kritis maupun partisipasi aktif sehingga memampukan anak muda sebagai konsumen media membuat tafsiran dan penilaian berdasarkan informasi yang diperolehnya, selain itu memampukan anak muda untuk menjadi prosedur media dengan caranya sendiri sehingga menjadi partisipan yang berdaya di masyarakatnya (Buckingham, 2011). Masyarakat sebagai pengguna media sosial perlu diberikan sisi edukasi berkaitan dengan etika serta aturan dalam penggunaan media sosial. Proses validasi media, baik itu media cetak, elektronik bahkan media sosial yang berbasis internet, harus dianalisis melalui proses pencaraian informasi dari beragam sumber dan validasi bertujuan untuk mencari keseimbangan informasi yang didapatkan. Pemahaman akan dampak buruknya literasi digital perlu ditekankan pada pengguna agar tidak terjadi hal-hal yang tidak diinginkan (Pratiwi \& Pritanova, 2017). Tren menunjukan bahwa mayoritas pengguna media sosial kalangan peserta didik adalah anak-anak dan remaja.

Dinamika penggunaan media sosial saat ini digunakan tidak maksimal dan terjadinya pembiasan berita yang tidak sesuai dengan fakta. Hal ini seharusnya menjadikan bagaimana kalangan milenial dan masyarakat menjadi melek politik bagi perkembangan kehidupan sosial. Begitu pesatnya perkembangan media sosial di Indonensia, maka setiap tahun selalu terjadi peningkatan. Berdasarkan data Asosiasi Penyelenggara Jasa Internet Indonesia (APJII) menyebutkan secara umum pengguna internet di seluruh dunia baik mobile maupun fixed mengalami kenaikan terus menerus. Demikian pula Indonesia pada tahun 2020, total pengguna internet mencapai lebih dari 196 juta jiwa atau total $72 \%$ dari total penduduk (Slamet, 2021). APJII juga melansir bagaimana perilaku pengguna internet yang berhubungan dengan kegiatan berpolitik yakni sebanyak $75,6 \%$ setuju media sosial digunakan untuk aktivitas berpolitik. 
Berdasarkan gambaran di atass terlihat bagaimana aktivitas media sosial dapat digunakan sebagai sarana berpolitik. Sekarang ini banyak juga tokoh politik yang memiliki akun media sosial baik facebook, twitter dan instagram begitu juga partai politik. Digunakannya media sosial sebagai sarana berpolitik tentu dapat memberikan peranan bagi pengembangan literasi politik masyarakat.

Penggunaan media sosial untuk kepentingan kegiatan politik dapat dilakukan oleh masyarakat khususnya kaum millennial sebagai sarana untuk menambah pengetahuan tentang kegiatan politik yang terjadi, melihat jalannya kegiatan politik dan berpartisipasi aktif dalam kegiatan politik. Pengembangan literasi politik yang baik menjadi vital keberadaanya dalam konteks pembangunan kualitas hidup secara demokratis dalam berbangsa dan bernegara. Pengembangan literasi politik melalui struktur pembentukan dan pengembangan sosialisasi dan edukasi yang memadahi dalam konteks sosial politik maka warga negara secara komprehensif akan memahami kedudukannya sebagai warga negara yang sadar akan hak dan kewajibannya. Hal tersebut akan berdampak terhadap timbulnya kesadaran yang otonom dalam partisipasi pembangunan politik dan demokrasi yang bermutu khususnya di Kabupaten Blitar.

Beberapa penelitian terdahulu hanya menjelaskan tentang peran media saja di dunia politik bukan tentang strategi komunikasinya seperti penelitian yang dilakukan Munzir (2019). Lainnya, penelitian yang dilakukan Anshari (2013) Politik di Era Media Sosial hanya menjelaskan peluang media sosial oleh aktor politik. Begitu juga dengan penelitian yang dilakukan Ardha (2014) dengan judul "Sosial Media sebagai Media Kampanye Partai Politik 2014 di Indonesia" yang hanya menjelaskan bahwa media sosial hanya sebagai platform untuk berinteraksi tanpa adanya strategi komunikasi politik.

Pada kenyataannya saat ini media sosial hanya sekedar platform interaksi saja atau sebatas untuk mendapatkan like (suka) atau komentar yang kadang hanya sekedar komentarkomentar biasa saja. Untuk itu seharusnya media sosial memiliki fungsi sebagai alat komunikasi pada konstituen dan masyarakat luas untuk membangun kedekatan emosional serta fungsi sebagai wadah aspirasi rakyat. Selain itu media sosial seharusnya digunakan untuk membentuk atau menciptakan brand atau citra partai politik dan juga kader partai politik.

\section{Metode Penelitian}

Penelitian tentang strategi komunikasi politik Partai Golkar Kabupaten Blitar melalui media sosial sebagai pendidikan politik pada pengembangan literasi digital masyarakat ini menggunakan jenis penelitian deskriptif kualitatif yang mengharuskan peneliti mengikuti formatformat penelitian kualitatif dari awal sampai akhir. Penelitian deskriptif kualitatif adalah metode penelitian yang berlandaskan pada filsafat post positivisme yang biasanya digunakan untuk meneliti pada kondisi objektif yang alamiah dimana peneliti berperan sebagai instrummen kunci (Sugiyono, 2002). Penelitian ini menggunakan paradigma post positivistik dengan pendekatan studi kasus.

Prosedur penelitian yang dilakukan meliputi tiga tahap. Pertama, Tahap deskripsi atau tahap orientasi. Pada tahap ini peneliti mendeskripsikan apa yang dilihat, didengar, dan dirasakan dengan melakukan observasi di lapangan. Tahap kedua adalah reduksi. Semua data yang diperoleh dari observasi di lapangan kemudian difokuskan pada rumusan masalah tertentu. Ketiga, tahap seleksi, yaitu dengan melakukan analisis yang lebih mendalam tentang fokus masalah penelitian. Adapun yang menjadi informan atau responden dalam penelitian ini adalah pengurus Partai Golkar, BAPILU (Badan Pemenangan Pemilu) Partai Golkar dan para Legislatif 
Partai Golkar yang terpilih memenangkan Pemilu 2019 di Kabupaten Blitar. Teknik pengambilan data dilakukan dengan wawancara, dokumentasi, literatur dan observasi. Teknik Analisis data dalam penelitian ini menggunakan teknk analisis data Milles and Habberman. Teori yang digunakan dalam penelitian ini yaitu strategi komunikasi Harold D. Laswell yang terdiri dari 5 komponen Who, Say What, In Which Channel, To Whom, With What Effect.

\section{Hasil dan Pembahasan}

Strategi dalam komunikasi merupakan usaha untuk mengatur pelaksanaan operasi komunikasi agar mampu mencapai target yang diinginkan. Strategi tidak hanya berfungsi sebagai peta jalan yang hanya menunjukkan arah tetapi juga harus menunjukkan taktik operasionalnya (Abidin, 2015). Oleh karena itu sebelum melakukan komunikasi, maka komunikator harus mampu terlebih dahulu membuat strategi komunikasi. Komunikasi sendiri adalah proses penyampaian suatu pesan dalam bentuk simbol atau kode dari satu pihak kepada pihak yang lain dengan efek untuk mengubah sikap atau tindakan. Strategi komunikasi yang dilakukan partai Golkar dalam melakukan pendidikan politik adalah terlebih dahulu menetapkan komponen-komponen yang terkandung dalam konsep komunikasi Harold D. Laswell, yaitu Who Says What to Whom in Which Channel with What Effect.

\section{Komunikator dalam Strategi Komunikasi Politik Partai Golkar}

Pada strategi yang pertama adalah menetapkan komunikator-atau komponen who dalam konsep Harold D. Laswell—dalam komunikasi politik yang dilakukan Partai Golkar. Sumber komunikasi menjadi sangat penting perannya dalam interaksi dan komunikasi dalam bentuk apa pun. Hal ini sangat signifikan dalam apa yang dilakukan Partai Golkar sebagai upaya pendidikan politik bagi pengembangan literasi masyarakat. Menimbang hal ini, maka ada beberapa komunikator komunikasi politik Partai Golkar yang ditetapkan sebagai bagian dari strategi komunikasi politik yang dilakukan, yaitu:

Satu, politikus. Pemimpin politik mengerahkan pengaruhnya ke dua arah yaitu mempengaruhi alokasi ganjaran dan mengubah struktur sosial yang ada atau mencegah perubahan demikian menurut Danniel Katz (Maarotong, 2020). Dalam kewenangannya yang pertama, politikus sebagai wakil suatu kelompok atau langganan. Pesan-pesan politikus itu mengajukan dan atau melindungi tujuan kepentingan politik, artinya komunikator politik mewakili kepentingan kelompok. Sebaliknya politikus yang bertindak sebagai ideologi tidak begitu terpusat perhatiannya kepada pendesakan tuntutan seorang langganan, ia lebih menyibukkan dirinya untuk menetapkan 'tujuan kebijakan yang lebih luas, mengusahaka reformasi dan bahkan mendukung perubahan revolusioner. Kedua, tipe politikus ini mempengaruhi orang lain, yakni mereka bertindak dengan tujuan mempengaruhi opini orang lain. Di dalam Partai Golkar para politikus Partai Golkar dianggap sebagai komunikator Partai Golkar di Kabupaten Blitar.

Dua, profesional. Di dalam Partai Golkar Kabupaten Blitar komunikator professional adalah peranan sosial relatif baru, suatu hasil sampingan dari revolusi komunikasi yang sedikitnya mempunyai dua dimensi utama, yaitu munculnya media massa yang melintasi batasbatas rasial, etnis, pekerjaan, wilayah, dan kelas untuk meningkatkan kesadaran identitas nasional dan perkembangan serta media khusus (seperti majalah untuk khalayak khusus, stasiun radio, dan sebagainya) yang menciptakan publik baru untuk menjadi konsumen informasi dan 
hiburan. Seorang komunikator profesional menurut James Carey sebagaimana yang dikutip Nimmo adalah seorang makelar simbol, orang yang menerjemahkan sikap, pengetahuan dan minat suatu komunitas bahasa ke dalam istilah-istilah komunitas bahasa yang lain yang berbeda tetapi menarik dan dapat dimengerti (Gantiano, 2018). Komunikator professional menghubungkan golongan elit dalam organisasi atau komunitas manapun dengan khalayak umum. Secara horizontal ia menghubungkan dua komunitas bahasa yang dibedakan pada tingkat struktur sosial yang sama. Maka komunikator profesional adalah manipulator dan makelar simbol yang menghubungkan para pemimpin satu dengan pemimpin yang lainnya dan para pengikut.

Tiga, aktivis atau terdapat juru bicara bagi kepentingan yang terorganisasi. Pada umumnya orang ini tidak memegang ataupun mencita-citakan jabatan pada pemerintah. Dalam hal ini komunikator tersebut tidak seperti politikus yang membuat politik menjadi lapangan kerjanya. Juru bicara biasanya juga profesional dalam komunikasi. Namun, berbicara untuk kepentingan yang terorganisasi merupakan peran yang serupa dengan peran politikus yang menjadi wakil partisipan, yakni mewakili tuntutan keanggotaan suatu organisasi dan tawar menawar untuk pemeriksaan yang mengguntungkan. Yang termasuk dalam hal ini juga jaringan interpersonal yang mencakup komunikator politik utama, yakni pemuka pendapat. Sebuah badan penelitian yang besar menunjukkan bahwa banyak negara yang dihadapkan pada pembuatan keputusan yang bersifat politis memintanya petunjuk dari orang-orang yang dihormati, apakah untuk mengetahui apa yang harus dilakukannya atau untuk memperkuat putusan yang telah dibuatnya (Maarotong, 2020).

Komunikasi terjadi dalam suatu matrik sosial. Situasi tempat komunikais bermula, berkembang dan berlangsung menerus adalah bagian intergral dari sistem sosial ini menurut J.D Halloran (Nimmo, 2005). Komunikasi massa sebagai organisasi yang menduduki posisi penting yang peka di dalam jaringan sosial, menanggapi berbagai tekanan dengan menolak dan memilih informasi, yang semuanya terjadi dalam ssstem sosial yang bersangkutan. Oleh karena itu komunikator politik ini memainkan peranan sosial yang utama, terutama dalam proses opini publik. Komunikator sebagai dirinya sendiri artinya melalui sikapnya terhadap khalayak atau publik potensial, martabat yang diberikannya kepada mereka sebagai manusia. Komunikator harus diidentifikasi dan kedudukan mereka dalam masyarakat harus ditetapkan. Hal ini relevan sekali denjelasan Nimmo (2005) di mana ada tiga kategori yang diidentifikasi sebagai komunikator politik yaitu politikus, komunikator yang professional dalam politik dan aktivis. Dikorelasikan dengan penjelasan tersebut, maka yang termasuk dalam komunikator di sini adalah pengurus partai Golkar, Ketua Partai Golkar, kader Partai Golkar dan anggota legislatif dari Partai Golkar Kabupaten Blitar. Termasuk pada pemilihan umum tahun 2024, para calon anggota legislatif pemilihan umum mendatang merupakan komunikator politik di mana setiap Dapil (Daerah pemilihan) ada sekurang-kurangnya 8-9 calon legislatif (caleg) yang nantinya akan didaftrakan Partai Golkar Kabupaten Blitar untuk mengikuti Pileg 2024. Model penjaringan yaitu berasal dari kader-kader Partai Golkar Kabupaten Blitar. Para caleg akan diseleksi berdasarkan hasil wawancara dengan panelis-panelis untuk mengukur keahlian dan kompetensi para calon legislatif yang memenuhi kriteria baik dari usia maupun pendidikan.

\section{Pesan Politik (Says What)}

Pesan merupakan suatu muatan atau konten komunikasi yang dikemas atau dikonstruksikan sebagai informasi yyang bermuatan politik dan ditransformasikan kepada 
khalayak dengan menggunakan media massa. Pesan politik merupakan salah satu unsur penting dalam komunikasi politik yang disampaikan oleh komunikator kepada komunikan dalam ragam pesan bisa berbentuk verbal dan non verbal. Pesan politik merupakan salah satu unsur penting dalam komunikasi politik yang disampaikan oleh komunikator kepada komunikan dalam ragam pesan bisa berbentuk verbal dan non verbal. Pesan politik yang disampaikan oleh Partai Golkar kabupaten Blitar terkait penyampaian informasi mengenai mengenai program kerja, visi dan misi. Dalam kampanye politik Partai Golkar Kabupaten Blitar perlu mengadakan dialog dengan masyarakat untuk menyampaikan visi dan misi serta program kerja yang benar-benar dibutuhkan oleh masyarakat.

Dalam prakteknya, komunikator politik membutuhkan saluran untuk menyampaikan pesannya, baik melalui komunikasi organisasi, komunikasi massa dan komunikasi interpersonal. Dalam kampanye politik, bentuk komunikasi yang efektif untuk menyampaikan pesan adalah komunikasi massa dengan menggunakan media massa baik cetak maupun elektronik serta media sosial. Banyak politisi yang mempunyai kepentingan menggunakan media massa untuk menyampaikan pesannya guna mempengaruhi publik. Partai Golkar Kabupaten Blitar menggunakan Faccebook dan Instagram dalam menyampaikan informasi terkait programprogram kerja partai Golkar. Selain iu juga melalui podcast yang dilakukan oleh Bidang komunikasi dan media Partai Golkar Kabupaten Blitar.

Sesuai dengan teori Laswell maka paradigm ini menyatakan bahswa unsur-unsur komunikasi tersebut berlaku dalam setiap proses komunikasi dan berlaku juga dalam komunikasi politik. Komunikasi politik senantiasa melibatkan pesan-pesan politik dan aktor-aktor politik. Pesan komunikasi politik Partai Golkar Kabupaten Blitar menekankan pada calon legislatif milenial, anti korupsi, berkarya dan anti intoleransi yang dikemas ke dalam gaya komunikasi kaum milenial. Muatan pesan tersebut dibawakan secara umum termasuk dalam mengomentari isu-isu yang terjadi atau menjadi perbincangan umum.

\section{Media (in which Channel)}

Di dalam tubuh Partai Golkar Kabupaten Blitar komunikator politik dituntut untuk kreatif menyampaikan pesan yang inovatif. Konvergensi media memberikan pengaruh dan dampak yang besar kepada audiens khususnya masyarakat dan para pemilih dalam pemilu. Konvergensi media merupakan penghubung media massa dan teknologi digital. Dampak yang mampu dihasilkan oleh pengaruh konvergensi media massa adalah (1) meningkatnya akses informasi, (2) penyampaian informasi yang lebih cepat, dan (3) komunikasi menjadi lebih interaktif, sehingga pengguna bisa semakin aktif memberikan komentar dan saran mengenai informasi dan konten yang diterima.

Komunikasi politik Partai Golkar Kabupaten Blitar dan para calon anggota legislatifnya pada dasarnya menggunakan media massa konvensional, media massa online hingga media sosial. Media massa online seperti portal berita online maupun Media sosial yang digunakan Partai Golkar Kabupaten Blitar memperoleh porsi yang lebih besar dibandingkan media konvensional seperti koran, surat kabar dan baliho. Mayoritas caleg menggunakan laman media sosial pribadi mereka untuk melakukan kampanye dalam bentuk narasi-narasi politik. Para caleg melakukan komunikasi selain secara tidak langsung juga melakukan komunikasi langsung dengan para calon pemilihnya, terutama dalam bentuk door-to-door communication. Dalam hal ini para caleg melakukan kunjungan ke rumah-rumah warga yang menjadi konstituen politiknya. 
Partai Golkar Kabupaten Blitar menitikberatkan perhtian pada suara-suara pendukung Partai Golkar Kabupaten Blitar sebelumnya dan para kaum milenial. Didasarkan pada titik fokus ini Partai Golkar Kabupaten Blitar lebih sering melakukan kampanye digital melalui media sosial. Pendekatan menggunakan media sosial sangat ekonomis, praktis dan memiliki jangkaun yang luas.

Selain daripada itu, Partai Golkar Kabupaten Blitar juga tetap menggunakan pemasangan baliho, spanduk di pinggir-pinggir jalan. Strategi yang sudah umum dan sudah lama digunakan oleh Parta-Partai politik untuk mengusung visi dan misinya dengan tujuan agar Partai Golkar Kabupaten Blitar dapat menambah kursinya di legislatif pada pemilu berikutnya.

\section{Khalayak (to Whom)}

Khalayak adalah suatu peran yang sementara sifatnya, penerima pesan akan memprakarsai penyampaian suatu pesan berikutnya. Maka pada saat itu pihak yang tadinya sebagai khalayak sudah berubah peran menjadi komunikator. Dalam komunikasi politik, khalayak yang menerima pesan-pesan politik adalah khalayak politik. Jadi, dengan berita dan informasi atau pesan yang mempunyai muatan politik dalam bentuk apapun adalah khalayak politik. Khalayak politik juga dapat berubah peran menjadi komunikator politik dalam situasi dan kepentingan tertentu. Target dan sasaran komunikasi politik para Caleg Partai Golkar Kabupaten Blitar dibagi menjadi tiga, yaitu (a) keluarga dan kerabat dekat, (b) para pemilih pemula yang terdiri dari teman-teman dan rekan calon legislative, dan (c) masyarakat umum.

\section{Efek (with What Effect)}

Efek dari strategi komunikasi politik yang digunakan para komunikator politik Partai Golkar Kabupaten Blitar dalam pemilu dapat berpengaruh pada khalayak dengan lebih cepat. Para audiens lebih cenderung memilih seorang calon legalistif karena secara tidak telah terkena terpaan berbagai macam kampanye politik. Cukup banyak strategi yang dilakukan Partai Golkar Kabupaten Blitar dalam Pemilu Legislatif. Strategi-strategi tersebut dapat membawa Partai Golkar Kabupaten Blitar memperoleh jumlah kursi yang cukup signifikan dalam Pemilu Legislatif. Strategi yang dilaksanakan oleh Partai Golkar Kabupaten Blitar sangat bervariasi, salah satunya melaksanakan kegiatan sosial di masyarakat. Sementara selama masa pandemi Covid 19 Partai Golkar Kabupaten Blitar lebih menekankan bantuan pada masyarakat yang terdampak Covid 19. Efek yang diharapkan Partai Golkar Kabupaten Blitar dapat mencapai komunikasi politik caleg Partai Golkar Kabupaten Blitar adanya pemahaman secaa kognitif mengenai visi dan misi serta muatan poisitif Partai Golkar Kabupaten Blitar. Hal ini diharapkan ke depannya masyarakat akan bersimpati dan menedukung Partai Golkar di Kabupaten Blitar. Hal ini berarti efek yang terjadi di masyarakat juga berdampak pada meningkatnya popularitas caleg dan partai politik.

\section{Pendidikan Politik Partai Golkar}

Pendidikan politik sebagai political forming atau political building. Disebut "forming" karena terkandung intensi untuk membentuk insan politik yang menyadari status atau kedudukan politiknya di tengah masyarakat. Sementara itu, disebut "building" (pembentukan atau pendidikan diri sendiri), karena istilah tersebut menyangkut aktivitas antara lain membentuk diri sendiri, dengan kesadaran penuh tanggung jawab sendiri untuk menjadi insan politik (Kartini, 2009). Pendidikan politik pada hakikatnya merupakan bagian dari pendidikan orang dewasa. 
Pendidikan macam ini tidak menonjolkan proses kultivasi individu menjadi "intelektual politik" yang bersinggasana dalam menara gading keilmuan, atau menjadi pribadi kritis dan cerdas "yang terisolasi" dari masyarakat lingkungannya. Akan tetapi, pendidikan politik lebih menekankan relasi individu dengan individu lain, atau individu dengan masyarakatnya di tengah medan sosial dalam satu konteks politik kaitannya pada aspek-aspek sosial-ekonomi-budaya, di tengah situasisituasi konflik yang ditimbulkan oleh bermacam-macam perbedaan atau oleh adanya pluriformitas (kemajemukan budaya) (Kartini, 2009).

Fungsi dari pendidikan politik adalah untuk meninggkatkan pengetahuan rakyat agar mereka dapat berpartisipasi secara maksimal dalam berpolitik. Partisipasi aktif masyarakat mempunyai pengaruh dan kekuatan. Rakyat bisa ikut dalam pengawasan terhadap perbuatan mengatur masyarakat dan Negara dengan menjalani proses politik melalui pendidikan politik dan belajar politik. Dalam hal ini, pendidikan politik yang dilakukan Partai Golkar Kabupaten Blitar adalah mengadakan seminar dengan tokoh-tokoh politik yang dilakukan melalui live IG (Instagram), siaran podcast dengan badan pemenangan pemilu (BAPILU) Partai Golkar Kabupaten Blitar, siaran langsung melalui Facebook Partai Golkar Kabupaten Blitar pada setiap seminar-seminar politik yang diadakan oleh Partai Golkar Kabupaten Blitar.

Pendidikan politik yang dilakukan Partai Golkar Kabupaten melalui media sosial tidak hanya untuk membentuk citra positif, melainkan juga untuk melakukan pengembangan literasi digital masyarakat. Strategi komunikasi politik melalui media sosial menjadi penting agar masyarakat menjadi terliterasi. Dengan strategi yang demikian masyarakat menjadi lebih paham mengenai ideologi partai dan pesan-pesan yang disampaikan lebih mudah dipahami sehingga kampanye partai politik menjadi sia-sia. Selain daripada itu, konten media sosial juga sangat penting sehingga dalam pembuatan konten seharusnya dibuat isi konten yang mengandung halhal positif atau jangan sampai membuat konten negatif yang dapat menjatuhkan citra partai politik.

Saat ini kampanye terbuka memang dinilai sudah tidak efektif lagi karena sangat menyedot anggaran sangat besar. Kehadiran massa yang begitu besar dalam sebuah kampanye terbuka bukan menjadi indikator kemenangan dalam pemilu (pemilihan umum) karena di balik keramaian massa disesaki beragan atribut dan terselip makna yang berararti. Segencar atau seproduktif apa pun sebuah partai politik melakukan kampanye di media sosial jika partai politik tersebut gagal menyampaikan ideologi atau pesan ke audiens atau massa maka kampanye tersebut menjadi hal yang percuma atau sia-sia. Oleh sebab itu, melalui media sosial partai politik dapat menyuarakan gagasan atau visi dan misi partai politik secara lebih komprehensif dan luas.

Strategi komunikasi politik yang dilakukan Partai Golkar tidak lepasdari kendala. Kendala-kendala tersebut tidak hanya berasal dari dalam (internal) malinkan juga berasal dari luar (eksternal). Kendala internal yang dihadapi Partai Golkar meliputi beberapa aspek. Pertama, kondisi psikologis kaum muda atau generasi milenial yang masih masih labil, sehingga terkadang menjadi penyebab konflik internal. Kedua, tidak mengelola dana operasional untuk kegiatan kampanye maupun perorangan caleg, bahkan dana perasional menjadi tanggung jawab masing-masing calon anggota legislatif. Ketiga, menyerahkan sepenuhnya permasalaahn strategi dan taktik pada masing-masing caleg sehingga terdapat perbedaan strategi dari masing-masing caleg Partai Golkar Kabupaten Blitar. Sebagai contoh, ada sejumlah caleg yang berkeliling dari rumah ke rumah, ada yang menempelkan stiker, ada yang memberikan kalender, dan ada juga 
yang membagikan kaus. Sementara itu, kendala eksternal yang dihadapi meliputi (1) pemberitaan media terkait beberapa pernyataan kontroversial elit politik, (2) terbentuknya opini publik yang negatif atau resistensi masyarakat terhadapat Partai Golkar, (3) adanya persaingan dari partai-partai politik lain.

\section{Kesimpulan}

Strategi komunikasi politik Partai Golkar Kabupaten Blitar dalam melakukan pendidikan politik melalui media sosial adalah terlebih dahulu menetapkan komponen-komponen komunikasi sebagaimana yang dijelaskan Harold D. Laswell, yaitu komunikator politik, pesan, khalayak politik, media dan efek yang diharapkan. Lembaga partai dan terutama para calon anggota legislatif, prefesional, politikus, aktivitas, dan pemuka pemdapat adalah orang-orang yang termasuk ke dalam komunikator politik. Lembaga partai terlebih dahulu menetapkan komponen-komponen tersebut sebelum kemudian melakukan komunikasi politik untuk melakukan pendidikan politik kepada masyarakat. Selanjutnya, untuk merebut suara masyarakat sebagai upaya untuk memenangkan pemilu legistatif DPRD Kabupaten Blitar lembaga partai Golkar menetapkan atau menentukan media sosial yang akan digunakan, yaitu Instagram dan Facebook. Dua media sosial tersebut dinilai dapat memberikan dampak yang besar karena dengan penggunaan media sosial Instagram dan facebook jangkauan informasi yang disampaikan lebih luas. Penggunaan media sosial tersebut juga lebih menghemat biaya atau dana anggaran dari partai politik dan para caleg.

Akan tetapi, penerapan strategi-strategi tersebut tidak lepas dari kendala-kendala, yang tidak hanya berasal dari dalam (internal) malainkan juga berasal dari luar (eksternal). Kendala internal meliputi (1) kondisi psikologis kaum muda atau generasi milenial yang masih masih labil, sehingga terkadang menjadi penyebab konflik internal, (2) tidak mengelola dana operasional untuk kegiatan kampanye maupun perorangan caleg, bahkan dana perasional menjadi tanggung jawab masing-masing calon anggota legislative, (3) lembaga partai menyerahkan sepenuhnya permasalahan strategi dan taktik pada masing-masing caleg sehingga terdapat perbedaan strategi dari masing-masing caleg Partai Golkar Kabupaten Blitar. Kendala eksternal dihadapi meliputi (1) pemberitaan media terkait beberapa pernyataan kontroversial elit politik, (2) terbentuknya opini publik yang negatif atau resistensi masyarakat terhadapat Partai Golkar, (3) adanya persaingan dari partai-partai politik lain.

\section{Saran}

Melihat realitas yang terjadi, sangat diharapkan Partai Golkar Kabupaten Blitar dapat melaksanakan evaluasi untuk mengatasi hambatan-hambatan strategi komunikasi politik yang sudah diterapkan. Penggunaan media sosial harus lebih efektif dan efisien karena biaya yang dikeluarkan cukup murah. Terlebih lagi dewasa ini masyarakat tidak dapat terlepas dari penggunaan gadget terutama media sosial.

\section{Daftar Pustaka}

Abidin, Y. Z. (2015). Manajemen Komunikasi: Filosofi, Konsep dan Aplikasi. Pustaka Setia. Anshari, F. (2013). Komunikasi Politik di Era Media Sosial. Jurnal Komunikasi, 8(1), 91-102.

Ardha, B. (2014). Ardha: Social Media Sebagai Media Kampanye Partai Politik 2014 Di Indonesia. In Jurnal Visi Komunikasi (Vol. 13, Issue 01).

Buckingham, D. (2011). Media Education. Polity. 
Cahyono, A. S. (2016). Pengaruh media sosial terhadap perubahan sosial masyarakat di Indonesia. Jurnal Ilmu Sosial \& Ilmu Politik Diterbitkan Oleh Fakultas Ilmu Sosial \& Politik, Universitas Tulungagung, 9(1).

Efendi, A., Astuti, P. I., \& Rahayu, N. T. (2017). Analisis Pengaruh Penggunaan Media Baru Terhadap Pola Interaksi Sosial Anak di Kabupaten Sukoharjo. Jurnal Penelitian Humaniora, 18(2), 12-24. https://doi.org/10.23917/humaniora.v18i2.5188

Flew, T. (2005). New Media: An Introduction. Oxford University Press.

Gantiano, H. E. (2018). Politikus Sebagai Komunikator Politik. Dharma Duta, 16(1). https://doi.org/10.33363/dd.v16i1.145

Kartini, K. (2009). Pendidikan Politik: Sebagai Bagian Pendidikan Orang Dewasa. Mandar Maju.

Kristiyono, J. (2015). Budaya Internet: Perkembangan Teknologi Informasi dan Komunikasi dalam Mendukung Penggunaan Media di Masyarakat. Scriptura, 5(1), 23-30. https://doi.org/10.9744/scriptura.5.1.23-30

Maarotong, J. (2020). Fungsi Partai Politik Sebagai Sarana Komunikasi Politik (Suatu Studi pada Partai Demokrasi Indonesia Perjuangan di Kecamatan Essang Kabupaten Kepulauan Talaud). JURNAL POLITICO, 10(2).

Munzir, A. A. (2019). Beragam Peran Media Sosial dalam Dunia Politik di Indonesia. JPPUMA Jurnal Ilmu Pemerintahan Dan Sosial Politik Universitas Medan Area, 7(2), 173-182. https://doi.org/10.31289/jppuma.v7i2.2691

Nimmo, D. (2005). Komunikasi Politik. Remaja Rosdakarya.

Nursalim, M. (2017). Peran Konselor dalam Mengantisipasi Krisis Moral Anak dan Remaja Melalui Pemanfaatan Media "Baru." Bikotetik (Bimbingan Dan Konseling Teori Dan Praktik), 1(2), 59-65. https://doi.org/10.26740/bikotetik.v1n2.p59-65

Pratiwi, N., \& Pritanova, N. (2017). Pengaruh Literasi Digital Terhadap Psikologis Anak dan Remaja. Semantik, 6(1), 11-24. https://doi.org/10.22460/semantik.v6i1p11.250

Priansa, D. J. (2017). Perilaku Konsumen dalam Bisnis Kontemporer (Bandung). Alfabeta.

Rafiq, A. (2020). Dampak Media Sosial Terhadap Perubahan Sosial Suatu Masyarakat. GLOBAL KOMUNIKA, 1(1), 18-29.

Sibarani, A. J. P. (2021). Pelatihan Pemanfaatan Media Sosial Sebagai Wadah Kreatif dalam Membangun Usaha di Desa Padamukti, Solokan Jeruk, Jawa Barat. IKRAITH-ABDIMAS, 4(1), 85-88.

Slamet, J. (2021). Pengguna Internet di Indonesia.

Sugiyono. (2002). Metode Penelitian Administrasi. Alfabeta. 